\title{
Exocrine and Endocrine Pancreatic Cancer pT1 TNM Finding v7
}

National Cancer Institute

\section{Source}

National Cancer Institute. Exocrine and Endocrine Pancreatic Cancer pT1 TNM Finding

v7. NCl Thesaurus. Code C90290.

Exocrine or endocrine pancreatic cancer with tumor limited to the pancreas, measuring 2 $\mathrm{cm}$ or less in greatest dimension.. (from AJCC 7th Ed.) 